\title{
Appropriate Mesh Size of Insect Screen for the Exclusion of the Cigarette Beetle, Lasioderma serricorne (F.) *
}

\author{
by \\ Toshihiro Imai \\ Leaf Tobacco Research Center, Japan Tobacco Inc., Oyama, Tochigi, Japan
}

\begin{abstract}
SUMMARY
Insect screens are often used in tobacco facilities to exclude insect pests. Previous studies using laboratory cultures indicated that screens with openings smaller than $1.0 \mathrm{~mm}$ are adequate to prevent the passage of the cigarette beetle, Lasioderma serricorne. The beetles from natural populations are rather heterogeneous, and their body sizes may vary. Studies were conducted to confirm the relationship between mesh sizes and the body sizes of the cigarette beetles that can pass through the screens and to elucidate the size distribution of wild beetles. The results revealed that meshes can protect against beetles whose thorax width is larger than the openings in the mesh. Additionally, the widths of the prothoraxes of wild beetles captured in pheromone traps, which were generally considered to be male, ranged from $727-1070 \mu \mathrm{m}(N=169)$, and approximately $90 \%$ of the beetles had thoraxes that were narrower than $1000 \mu \mathrm{m}$. These data led to the conclusion that a $1.0 \mathrm{~mm}$ opening mesh is insufficient to protect against the cigarette beetle. Thus, Tyler standard \#24 mesh (= US standard \#25 mesh: $0.71 \mathrm{~mm}$ opening/sieve size) is recommended as an insect screen for tobacco facilities. [Contrib. Tob. Nicotine Res.] 30 (2021) 25-28]
\end{abstract}

\section{ZUSAMMENFASSUNG}

In tabakverarbeitenden Betrieben werden häufig Insektenschutzgitter eingesetzt, um Schädlinge fernzuhalten. Frühere Studien mit Laborkulturen deuteten darauf hin, dass Schutzgitter mit Öffnungen von unter 1,0 mm geeignet sind, um das Eindringen des Tabakkäfers Lasioderma serricorne zu verhindern. Käfer aus natürlichen Populationen sind eher heterogen und ihre Körpergröße kann variieren. Es wurden Studien durchgeführt, um den Zusammenhang zwischen der Maschenweite und der Körpergröße der Tabakkäfer, die durch den Insektenschutz gelangen, zu bestätigen, sowie die Größenverteilung bei Wildkäfern zu untersuchen. Die Studien ergaben, dass Schutzgitter vor Käfern, deren Thoraxbreite größer ist als die Weite der Maschen des Insektenschutzgitters, schützen können. Zudem lag die Breite des Prothorax von in Pheromonfallen gefangenen Wildkäfern, die grundsätzlich als männlich klassifiziert wurden, zwischen 727-1070 $\mu \mathrm{m}(N=169)$ und bei ca. $90 \%$ der Käfer lag die Thoraxbreite bei unter $1000 \mu \mathrm{m}$. Aus diesen Daten ergab sich die Schlussfolgerung, dass eine Maschenweite von 1,0 mm für den Schutz vor Tabakkäfern nicht ausreicht. Daher wird das Tyler Standard \#24 Mesh (= US Standard \#25 Mesh: 0,71 mm Öffnung/Maschenweite) als Insektenschutzgitter für tabakverarbeitende Betriebe empfohlen. [Contrib. Tob. Nicotine Res.] 30 (2021) 25-28]

\section{RESUME}

Des moustiquaires sont fréquemment utilisées dans les installations de traitement du tabac afin d'éloigner les insectes nuisibles. Par le passé, des études recourant à des cultures en laboratoires indiquèrent que les moustiquaires avec des mailles d'une taille inférieure à 1,0 mm offraient

* Received: $23^{\text {rd }}$ October 2020 - accepted: $25^{\text {th }}$ January 2021 
une protection adéquate contre les incursions du lasioderme du tabac (Lasioderma serricorne). Les coléoptères issus des populations naturelles présentent des caractéristiques plutôt hétérogènes et la taille de leur corps peut varier. Des études furent menées dans le but de confirmer la corrélation entre la taille du maillage et les dimensions corporelles des lasiodermes du tabac capables de se faufiler à travers les moustiquaires et d'expliquer la répartition par taille des coléoptères sauvages. Les résultats révélèrent qu'un maillage pouvait offrir une protection contre les coléoptères dont la largeur du thorax était supérieure à la taille des orifices du maillage. En outre, les largeurs du prothorax des coléoptères sauvages capturés à l'aide de pièges à phéromones sexuelles, qui furent, en règle générale, considérés comme des individus males, variaient entre 727 et $1070 \mu \mathrm{m}(N=169)$ et environ $90 \%$ des coléoptères présentaient un thorax plus étroit que $1000 \mu \mathrm{m}$. Ces données permirent de conclure qu'une ouverture des mailles de 1,0 mm ne suffisait pas à se protéger des lasiodermes du tabac. Par conséquent, la norme Tyler \#24 mesh (= norme américaine \#25 mesh: $0,71 \mathrm{~mm}$ ouverture de filtration/calibre du tamis) est recommandée pour les moustiquaires dans les installations de traitement du tabac. [Contrib. Tob. Nicotine Res.] 30 (2021) 25-28]

\section{INTRODUCTION}

Insect screens installed on doors, windows, and other openings act as a mechanical barrier that prevents insects from entering warehouses and manufacturing facilities. They are available in different mesh sizes. There is a tradeoff between air permeability and insect proofing when selecting a screen mesh - the exclusion of smaller insects requires the installation of finer mesh screens, which inevitably obstructs air flow. To maintain good ventilation through windows, there is a necessity to keep the screen resistance to airflow as low as possible. In the food industry, a 16 mesh for the exclusion of stored product insects (1) or a $14 \times 18$ or $16 \times 16$ mesh screen for flies (2) is recommended.
For the cigarette beetle, Lasioderma serricorne, a 20 mesh (or a screen with an opening less than $1.0 \mathrm{~mm}$ ) is suggested (3-6). Adult body size is affected by and changes with factors such as the nutritional quality of food during the larval stage (7).

The studies were conducted to confirm the relationship between mesh sizes and the sizes of the cigarette beetles that can pass through the screen and to elucidate the size distribution of beetles from natural populations. Based on the results, the proper/maximum mesh size will be suggested for the exclusion of this important tobacco pest.

\section{MATERIALS AND METHODS}

\section{Test insects}

The cigarette beetles used in this study came from our laboratory culture which has been maintained on tobacco for more than 30 years. They were reared under conditions of $27{ }^{\circ} \mathrm{C}, 60 \%$ relative humidity and $14 \mathrm{~h}$ (light phase): $10 \mathrm{~h}$ (dark phase) in photoperiod. The adult insects were collected from rearing containers within one week after emergence and supplied for the test.

\section{Measurement of the sizes of adults passing through meshes}

Four cylindrical polystyrene containers $(12 \mathrm{~cm}$ i.d. at the bottom and $8 \mathrm{~cm}$ in height; sides slightly tapered), three of which had a $10 \mathrm{~cm} ø$ hole in the bottom, were stacked on top of each other, and polypropylene insect screens (\#24 mesh: $0.66 \mathrm{~mm}$ opening, \#20 mesh: $0.84 \mathrm{~mm}$ opening, and \#18 mesh: 1.0 mm opening; Innovex Co. Ltd., Tokyo, Japan) were tucked between the containers. The top container was closed with a lid with a $0.1 \mathrm{~mm}$-mesh gauze insert (Figure 1). Approximately 200 unsexed adults were released into the bottom compartment and maintained under rearing conditions. After $24 \mathrm{~h}$, the beetles that had passed through the screens and remained in the different compartments were counted and the width of their prothoraxes was measured under a microscope after they were killed by freezing.

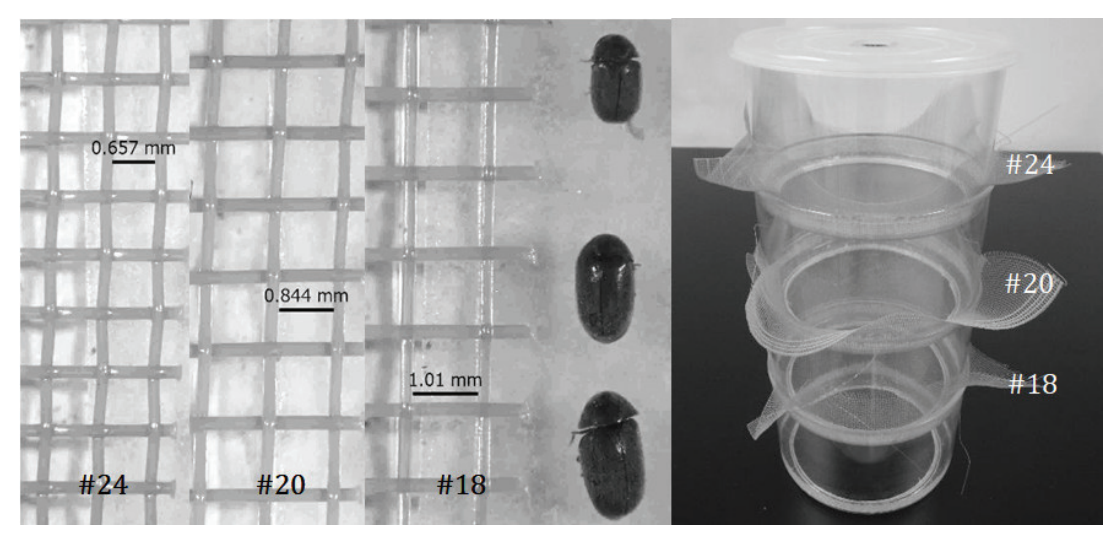

Figure 1. Screening meshes in comparison with adult cigarette beetles (left and center images). Test apparatus (right). Polystyrene containers $(12 \mathrm{~cm} \varnothing \times 8 \mathrm{~cm})$ with 10 $\mathrm{cm}$ holes in the bottom, between which polypropylene meshes with $0.66 \mathrm{~mm}, 0.84 \mathrm{~mm}$, or $1.0 \mathrm{~mm}$ openings were placed, were stacked on top of each other, and the lid of the top container was closed. Approximately 200 unsexed adults were released in the bottom compartment. 


\section{Measurement of the sizes of adults from natural populations}

Adult cigarette beetles from natural populations were captured by using pheromone traps (Serrico ${ }^{\circ}$, Fuji Flavor Co. Ltd., Tokyo, Japan) in the area around three tobacco factories located in Japan during July and August, 2017. During these collection periods, 169 adults were captured, and the width of their prothoraxes was measured in the same manner as described above.

\section{RESULTS AND DISCUSSION}

The prothorax widths of the beetles that passed through the screens and remained in the compartments ranged from 806-984 $\mu \mathrm{m}(N=14)$ for the \#18 mesh (1.0 mm opening), 769-839 $\mu \mathrm{m}(N=8)$ for the \#20 mesh (0.84 mm opening), and $685 \mu \mathrm{m}(N=1)$ for the \#24 mesh $(0.66 \mathrm{~mm}$ opening) (Figure 2). The results suggest that the insect screens effectively prevented the entry of beetles with a prothorax wider than the opening size of the mesh. Only one beetle, with a $685 \mu \mathrm{m}$ wide prothorax, passed through a slightly finer mesh ( $0.66 \mathrm{~mm}$ opening), possibly owing to the flexibility of the polypropylene-fiber grid.

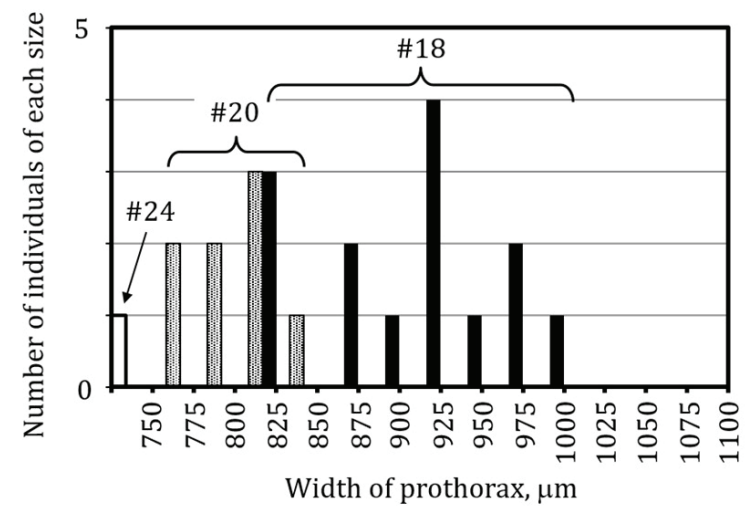

Figure 2. Distribution of the widths of prothoraxes of the laboratory-reared cigarette beetles that passed through \#24 (open bar), \#20 (dotted bar), and \#18 (filled bar) meshes.

The widths of prothoraxes of the adults captured in the pheromone traps around tobacco factories, most of which were considered to be males, ranged from $727-1070 \mu \mathrm{m}$ $(899.6 \pm 73.8$, mean $\pm \mathrm{SD} ; N=169)$, and no beetles with prothorax widths narrower than $710 \mu \mathrm{m}$ were observed. Approximately $15 \%$ of the beetles were smaller than $850 \mu \mathrm{m}$ and $90 \%$ were smaller than $1,000 \mu \mathrm{m}$ (Figure 3). Because females are larger than males on average (8), females will be excluded in higher proportions by the respective meshes. Nevertheless, a considerable proportion of wild cigarette beetles can pass through a 1-mm mesh, which has been recommended in previous publication (3-6).

These screens are generally defined by mesh sizes, which only indicates the number of threads per linear inch in each direction, and in addition to differences between different commercial brands, the effective opening (aperture) of the mesh varies with the width of the threads. Tyler standard \#20 mesh (= US standard \#20 mesh: $0.85 \mathrm{~mm}$ opening/ sieve size) is insufficient to protect against the cigarette beetle, and Tyler standard \#24 mesh (= US standard \#25 mesh: $0.71 \mathrm{~mm}$ opening/sieve size) or an equivalent-sized mesh, is recommended as an insect screen for tobacco facilities.

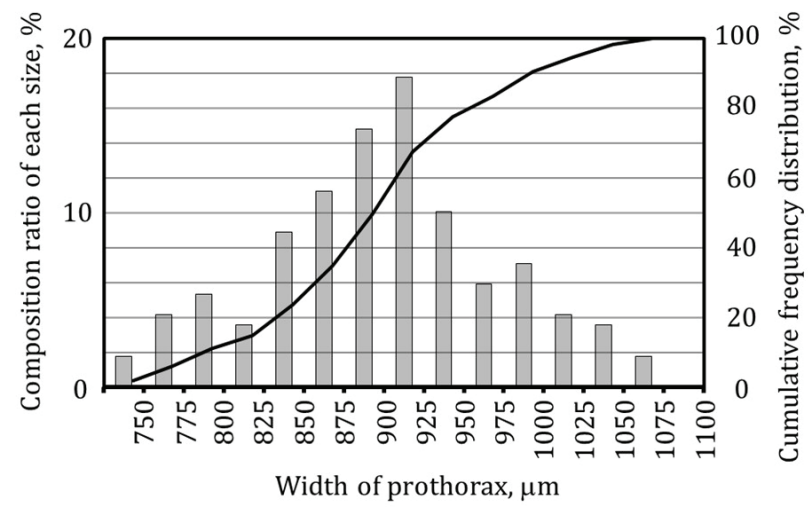

Figure 3. Frequency distribution of the widths of the prothoraxes of the wild cigarette beetles captured in pheromone traps around three tobacco factories in Japan during July and August 2017. Bars represent the composition ratio (left scale), and line represents the cumulative frequency (right scale).

\section{REFERENCES}

1. Heaps, J.W.: Food Plant Sanitation, Pest Exclusion, and Facility Design; in: Stored Product Protection; edited by D.W. Hagstrum, T.W. Phillips and G. Cuperus, Kansas State University, Manhattan, KS, USA, 2012, pp. 85-93. Available at: https://bookstore.ksre.ksu.edu/ pubs/s156.pdf (accessed January 2021)

2. Mason, L.: Insects and Mites; in: Food Plant Sanitation; edited by Y.H. Hui, B.L. Bruinsma, J.R. Gorham, W.K. Nip, P.S. Tong and P. Ventresca, CRC Press, Boca Raton, FL USA, 2002, pp. 293-316.

3. Vinzant, J.P. and W.D. Reed: Type of Wire Screen Required for Excluding Cigarette Beetles and Tobacco Moths From Warehouses; J. Econ. Entomol. 34 (1941) 724. DOI: $10.1093 /$ jee/34.5.724

4. U.S. Department of Agrigulture (USDA) - StoredProduct Insects Research Branch: Stored-Tobacco Insects: Biology and Control; Agricultural Handbook 233, USDA Agricultural Marketing Service, Washington DC (1962) 39 pp. Available at: naldc.nal.usda.gov/ download/CAT87208479/PDF (accessed January 2021)

5. Ryan, L. (ed.): Post-Harvest Tobacco Infestation Control; Kluwer Academic Publishers, Dordrecht, NL, 1995, 155 pp.

6. Adler, C.: Significance of Hermetic Seals, Controlled Ventilation, and Wire-Mesh Screens to Prevent the Immigration of Stored Product Pests; International Organization for Biological and Integrated Control, IOBC/WPRS Bulletin 27 (2004) 13-16. Available at: https://www.yumpu.com/en/document/view/4224131/io bc-wprs-bulletin-vol-27-9-2004 (accessed January 2021)

7. Mahroof, R.M. and T.W. Phillips: Life History Parameters of Lasioderma serricorne (F.) as Influenced by Food Sources; J. Stored Prod. Res. 44 (2008) 219-226. DOI: 10.1016/j.jspr.2007.12.001 
8. Kohno, M.: A Rapid Suction Method for Selective Collection of Small Beetles From Mass Culture; Appl. Entomol. Zool. 17 (1982) 135-136.

DOI: $10.1303 /$ aez17.135

\section{Corresponding author}

\section{Toshihiro Imai}

Leaf Tobacco Research Center

Japan Tobacco Inc.

Idei 1900, Oyama,

Tochigi 323-0808

Japan

E-mail: toshihiro.imai@jt.com 